\title{
Formulasi Sediaan Lotion Ekstrak Etanol Daun Salam (Syzygium polyanthum (Wight) Walp.) dan Penentuan Nilai SPF Secara in Vitro
}

\author{
Angling Nurisna Utami ${ }^{1 *}$, Wahida Hajrin ${ }^{1}$, Handa Muliasari ${ }^{1}$ \\ ${ }^{1}$ Program Studi Farmasi, Fakultas Kedokteran, Universitas Mataram, Mataram, Indonesia
}

\section{INFO ARTIKEL \\ Sejarah artikel: \\ Penerimaan naskah: 5 Februari 2021 \\ Penerimaan naskah revisi: 22 Februari 2021 Disetujui untuk dipublikasikan: 29 Maret 2021}

Kata kunci :

Daun salam, tabir surya, nilai SPF

\section{A B S T R A K}

Sinar Ultraviolet (UV) merupakan sebagian kecil dari spektrum sinar matahari yang sampai ke permukaan bumi dan paling berbahaya bagi kulit sehingga dibutuhkan tabir surya untuk mencegah gangguan akibat sinar UV tersebut. Daun salam mengandung senyawa fenolik, flavonoid, dan tanin yang berpotensi sebagai tabir surya. Tujuan dari penelitian ini yaitu untuk menentukan formula, karakteristik fisik, dan nilai SPF dari lotion ekstrak etanol daun salam (Syzygium polyanthum (Wight) Walp.). Pada penelitian ini, daun salam diekstraksi dengan metode sonikasi menggunakan pelarut etanol 96\%. Ekstrak tersebut diformulasikan dalam bentuk sediaan lotion kemudian dilakukan evaluasi sifat fisik. Selanjutnya dilakukan penentuan nilai SPF pada ekstrak dan sediaan lotion yang mengacu pada persamaan Mansur menggunakan instrumen spektrofotometer UV-Vis. Konsentrasi ekstrak daun salam yang digunakan pada formula sediaan lotion yaitu $0,1 \%(\mathrm{~F} \neg 1)$ dan $0,5 \%(\mathrm{~F} \neg 2)$. Hasil sifat fisik dari sediaan yaitu berwarna krem (F1) dan berwarna hijau kecoklatan (F2), aroma khas ekstrak daun salam, bertekstur lembut dan homogen, memiliki tipe emulsi M/A, daya sebar 5,92 cm (F1) dan 6,05 cm(F2), daya lekat 0,86 detik (F1) dan 0,78 detik (F2), pH 7,82 (F1) dan 7,74 (F2), serta nilai akseptabilitas yang sangat baik. Berdasarkan hasil uji sifat fisik tersebut, lotion ekstrak daun salam memenuhi syarat pada uji homogenitas, daya sebar, dan $\mathrm{pH}$, serta tidak memenuhi syarat pada uji daya lekat. Nilai SPF sediaan lotion ekstrak daun salam yaitu 4,97 (F1) dan 6,72 (F2) dengan tipe proteksi sedang dan ekstra. Semakin tinggi nilai SPF maka semakin tinggi tingkat proteksi terhadap sinar UV sehingga lotion F2 lebih baik dibandingkan F1.

\section{Formulation of Lotion From Bay Leave (Syzygium Polyanthum (Wight) Walp.) Ethanolic Extract And In Vitro Determination of Spf Value \\ Keywords: \\ $A B S T R A C T$}

Bay leaf, sunscreen, SPF value
Ultraviolet (UV) rays are a fraction of the spectrum of sunlight that reaches the earth's surface and it is the most dangerous for the skin, therefore sunscreen is needed to prevent the dangerous caused by the UV rays. Bay leaves contain phenolic, flavonoids, and tannin compounds that have potential as a sunscreen. The aim of this study was to determine the formula, physical characteristics, and SPF value of the ethanol extract lotion of bay leaf (Syzygium polyanthum (Wight) Walp.). In this study, the bay leaves were extracted by sonication method using $96 \%$ ethanol. The extract was formulated in a lotion dosage form and then evaluated its physical properties. Furthermore, the SPF value of the extract and lotion preparations was determined based on the Mansur equation using a UV-Vis spectrophotometer instrument. The concentration of bay leaf extract used in the lotion preparation formulas were $0.1 \%(\mathrm{~F} 1)$ and $0.5 \%(\mathrm{~F} 2)$. The results of the physical properties of the lotion is creamy color (F1) and brownish green color (F2), the distinctive smell of bay leaf extract, soft and homogeneous texture, O/W emulsion type, the spreadability are $5.92 \mathrm{~cm}(\mathrm{~F} 1)$ and $6.05 \mathrm{~cm}(\mathrm{~F} 2)$, stickiness 0.86 seconds $(\mathrm{F} 1)$ and 0.78 seconds (F2), pH 7.82 (F1) and 7.74 (F2), and have a very good acceptability values. Based on the results of the physical properties test, the bay leaf extract lotion meet the requirements on the homogeneous, spreadability, and $\mathrm{pH}$ test, also did not meet the requirements on the stickiness test. The SPF value in the bay leaf extract lotion were $4.97(\mathrm{~F} 1)$ and $6.72(\mathrm{~F} 2)$ with moderate and extra protection's type. The higher the SPF value, the higher the lever of protection against UV rays so that F2 lotion is better than F1 


\section{Pendahuluan}

Indonesia merupakan daerah tropis yang memiliki intensitas radiasi matahari yang tinggi. Sinar matahari memiliki banyak manfaat tetapi juga mempunyai efek yang merugikan bagi manusia.1 Sinar Ultraviolet (UV) merupakan sebagian kecil dari spektrum sinar matahari yang sampai ke permukaan bumi. Namun, sinar ini paling berbahaya bagi kulit karena paparan yang berlebihan dapat menyebabkan gangguan pada kulit seperti hiperpigmentasi, kulit terbakar, penuaan dini, kulit hitam, bersisik, dan kanker kulit.2

Kanker kulit masih terjadi di Indonesia. Berdasarkan data Globocan Cancer Observatory pada tahun 2020, kanker kulit melanoma di Indonesia terjadi sebanyak $0,41 \%$ dengan 3151 kasus.3Selain itu, sebanyak $57,35 \%$ mahasiswi usia 18-21 tahun mengalami penuaan kulit yang diakibatkan oleh sinar matahari dan kebanyakan subjek tidak atau salah menggunakan tabir surya.4

Tabir surya dibutuhkan untuk menjaga kulit dari paparan sinar mataharikarena aktivitas sehari-hari sebagian besar dilakukan di luar ruangan yang cenderung terpapar sinar matahari. Namun, produk tabir surya yang beredar di pasaran sebagian besar mengandung bahan aktif senyawa sintetik yang memiliki efek samping bagi penggunanya.5Bahkan pada tahun 1994 telah dilakukan penelitian oleh Collins dan Ferguson dimanaterjadi Photoallergic Contact Dermatitis (PCD) pada penggunaan Oksibenzon.6Oleh karena itu, pengembangan tabir surya saat ini lebih mengarah pada pemanfaatan bahan-bahan alam dengan alasan bahan alam lebih murah, mudah didapatkan serta diyakini tidak memiliki efek samping yang berbahaya bila dibandingkan dengan bahan-bahan kimia sintetis.7

Salah satu tanaman yang berpotensi sebagai tabir surya yaitu daun salam (Syzygium polyanthum (Wight) Walp.). Potensi daun salam sebagai tabir surya didukung oleh hasil penelitian Verawati dkk (2017) yang melaporkan ekstrak etanol $70 \%$ daun salam memiliki aktivitas antioksidan kategori sangat kuat dengan nilai IC50 $35,057 \mu \mathrm{g} / \mathrm{mL} .8$ Pemberian antioksidan pada kulit dapat mencegah proses kerusakan kolagen oleh ROS (Reactive Oxygen Species) yang terbentuk selama paparan sinar UV.9 Secara tradisional, daun salam digunakan untuk mengobati kolesterol tinggi, kencing manis, hipertensi, gastritis, dan diare.10 Kandungan senyawa metabolit sekunder dalam ekstrak daun salam yaitu fenolik, flavonoid, steroid, saponin, triterpenoid, alkaloid dan tanin.11 Fenolik dan flavonoid merupakan senyawa utama yang memiliki potensi sebagai tabir surya, karena senyawa tersebut mempunyai gugus kromofor yang dapat menyerap sinar UV.12

Sediaan tabir surya yang paling sering digunakan yaitu dalam bentuk lotion. Lotion lebih mudah digunakan pada kulit karena konsistensinya yang tidak terlalu padat sehingga dapat menyebar lebih merata pada permukaan kulit yang luas, sertacepat kering setelah pemakaian.13Tingkat perlindungan sediaan tabir surya terhadap sinar matahari dinyatakan dengan nilai SPF (Sun Protection Factor). Nilai SPF dapat menjadi salah satu pertimbangan dalam memilih suatu tabir surya, karena semakin tinggi nilai SPF maka semakin tinggi tingkat perlindungan terhadap sinar UV.14

Berdasarkan beberapa penelitian, tingginya aktivitas antioksidan ekstrak sebanding dengan tingginya nilai SPF. Oleh karena itu, ekstrak daun salam yang memiliki aktivitas antioksidan sangat kuat diharapkan memiliki nilai SPF yang tinggi sehingga dapat melindungi kulit dari sinar matahari. Tujuan dari penelitian ini yaitu untuk menentukan formula, karakteristik fisik, dan nilai SPF dari lotion ekstrak etanol daun salam (Syzygium polyanthum (Wight) Walp.)..

\subsection{Metode}

Bahan

Bahan yang digunakan dalam penelitian yaitu daun salam yang berasal dari daerah Praya Lombok Tengah, etanol 96\% teknis(Merck), aquades, ferri klorida $1 \%$ (Merck), ferri klorida 5\% (Merck), asam klorida pekat (Merck), serbuk Mg (Merck), etanol p.a. (Merck), aqua rosae.Bahan-bahan seperti trietanolamin teknis, asam stearat, setil alkohol, propilen glikol teknis, parafin cair teknis, metil paraben, propil paraben, dan metilen blue diperoleh dari CV. Bina Mitra.

\section{Alat}

Peralatan yang digunakan dalam penelitian ini adalah timbangan analitik (Ohaus), alat-alat gelas (Iwaki), mortar dan stamper, hot plate (Labnet), $\mathrm{pH}$ meter (Hanna Instruments), kaca objek, beban $80 \mathrm{~g}$ dan $100 \mathrm{~g}$, stopwatch, rotary evaporator (Hahn Shin), Sonikator (Elmasonic) dan Spektrofotometer UV-Visible Specord 200.

\section{Prosedur Penelitian \\ Pembuatan Simplisa dan Ekstraksi Sampel}

Pembuatan simplisia dilakukan dengan $1,7 \mathrm{~kg}$ daun salam segar dipisahkan dari kotoran dan bahan asing, dicuci, ditiriskan, dan dirajang. Sampel yang telah dirajang dikeringkan di bawah sinar matahari selama 6 hari. Simplisia disimpan pada wadah inerttertutup dan diberi silica gel.

Ekstraksi daun salam dilakukan dengan 300 gram simplisia dihaluskan dengan menggunakan blender dan diekstraksi menggunakan metode sonikasi dengan perbandingan simplisia dan pelarut etanol $96 \%$ adalah 1:10. Sampel disaring dan residu ditambahkan lagi pelarut yang sama (3 liter) hingga tiga kali. Filtrat kemudian disatukan dan dipekatkan menggunakan rotary evaporator pada suhu $40^{\circ} \mathrm{C}$ hingga diperoleh ekstrak kental. Kemudian dihitung persen rendemen ekstrak. 


\section{Uji Fitokimia Ekstrak}

Uji fenolik dilakukan dengan cara melarutkan 0,5 gram sampel dalam $5 \mathrm{~mL}$ aquades kemudian disaring dan direaksikan dengan 2 tetes larutan $\mathrm{FeCl}_{3} 5 \%$.Uji flavonoid dilakukan dengan cara melarutkan 0,5 gram sampel dalam $5 \mathrm{~mL}$ air panas, dididhkan 5 menit, lalu disaring. Filtrat kemudian ditambahkan dengan 0,1 gram serbuk $\mathrm{Mg}, 1 \mathrm{~mL}$ asam klorida pekat dan $2 \mathrm{~mL}$ etanol 96\%.Sedangkan uji tanin dilakukan dengan cara 0,5 gram sampel dipanaskan dengan $20 \mathrm{ml}$ aquades lalu disaring.Kemudian ditambahkan dengan 2 tetes $\mathrm{FeCl}_{3} 1 \%$.

\section{Penentuan nilai SPF ekstrak}

Larutan standar dibuat dengan megencerkan larutan induk ekstrak daun salam $0,1 \%$ menggunakan etanol p.a hingga diperoleh konsentrasi0,001\% dan 0,005\%. Kemudian dicatat absorbansi masing-masing konsentrasi pada panjang gelombang antara 290-320 nm tiap interval 5 $\mathrm{nm}$ pada spektrofotometer UV-Vis dan digunakan etanol p.a. sebagai blanko. Nilai SPF dihitung dengan persamaan Mansur pada Persamaan 1dan nilai EE $\times$ I ditunjukkan pada Tabel 1. ${ }^{15}$ Dilakukan tiga kali penentuan tiap poinnya.

$\mathrm{SPF}_{\text {spectrophotometri }}=\mathrm{CF} \times \sum_{290}^{320} \mathrm{EE}(\lambda) \times \mathrm{I}(\lambda) \times \operatorname{Abs}(\lambda) \ldots \ldots \ldots . .1$

Dimana:

EE $\quad=$ Spektrum efek erytemal

I $=$ Spektrum intensitas dari matahari

Abs = Nilai serapan yang terbaca

$\mathrm{CF} \quad=$ Faktor koreksi (10)

Tabel 1. Nilai EE $\times$ I

\begin{tabular}{ll}
\hline Panjang gelombang $(\mathbf{n m})$ & Nilai EE $\times \mathbf{I}$ \\
\hline 290 & 0,0150 \\
\hline 295 & 0,0817 \\
\hline 300 & 0,2874 \\
\hline 305 & 0,3278 \\
\hline 310 & 0,1864 \\
\hline 315 & 0,0839 \\
\hline 320 & 0,0180 \\
\hline
\end{tabular}

\section{Formulasi Sediaan Lotion}

Formula sediaan lotion ditunjukkan pada Tabel 2. Bahan-bahan yang larut minyak seperti asam stearat, setil alkohol, parafin cair dan propil paraben dimasukkan ke dalam cawan penguap dan dipanaskan pada suhu $70^{\circ} \mathrm{C}$, dicampur hingga homogen. Bahan-bahan larut air seperti trietanolamin (TEA), propilen glikol, metil paraben, dan sisa air dileburkan pada suhu $70^{\circ} \mathrm{C}$ dan dihomogenkan. Kemudian fase minyak dimasukkan sedikit demi sedikit ke dalam fase air pada suhu $70^{\circ} \mathrm{C}$, diaduk homogen hingga terbentuk lotion. Kemudian ditambahkan ekstrak daun salam dan aqua rosae, diaduk hingga homogen.

Tabel 2. Formula Lotion Ekstrak Daun Salam

\begin{tabular}{lll}
\hline Bahan & $\mathbf{F}_{\mathbf{1}}(\boldsymbol{\%})$ & $\mathbf{F}_{\mathbf{2}} \mathbf{( \% )}$ \\
\hline Ekstrak etanol daun salam & 0,1 & 0,5 \\
\hline TEA & 1 & 1 \\
\hline Asam stearat & 3 & 3 \\
\hline Setil alkohol & 2 & 2 \\
\hline Propilen glikol & 15 & 15 \\
\hline Parafin cair & 2,5 & 2,5 \\
\hline Metil paraben & 0,2 & 0,2 \\
\hline Propil paraben & 0,04 & 0,04 \\
\hline Aqua rosae & 3 tetes & 3 tetes \\
\hline Aquadest & ad 100 & ad 100 \\
\hline
\end{tabular}

\section{Evaluasi Sediaan Lotion}

Pengujian organoleptis dilakukan dengan mengamati parameter warna, bau, dan tekstur dari sediaan. Pengujian homogenitas dilakukan dengan 0,1 gram sediaan dioleskan tipis pada kaca objek secara merata kemudian diamati adanya butiran-butiran kasar.

Pengujian daya sebar dilakukan dengan 0,5 gram lotion diletakkan di tengah lapisan kaca. Kemudian diletakkan lapisan kaca lainnya di atas lotion, dibiarkan selama 1 menit. Diukur diameter lotion yang menyebar dari berbagai sisi. Setelah itu ditambahkan beban 100 gram, didiamkan 1 menit dan diukur diameter penyebaran lotion dari berbagai sisi.

Pengujian daya lekat dilakukan dengan mengoleskan sediaan secukupnya di atas kaca objek dan ditutup dengan kaca objek lain. Kemudian ditekan dengan beban $1 \mathrm{~kg}$ selama 5 menit. Beban diangkat dan kedua kaca objek yang berlekatan tersebut dilepaskan sambil dicatat waktu terlepasnya kedua kaca objek.

Pengujian $\mathrm{pH}$ dilakukan dengan $0,5 \mathrm{~g}$ sediaan dilarutkan dalam $50 \mathrm{~mL}$ aquades kemudian diukur $\mathrm{pH}$ dengan $\mathrm{pH}$ meter. Pengujian dilakukan dengan replikasi triplo untuk masing-masing formula.

Pengujian tipe emulsi dilakukan dengan mengoleskan sediaan pada kaca objek, lalu diteteskan larutan metilen blue. Apabila zat warna tersebar merata pada sediaan maka tipe emulsi M/A, tetapi jika zat warna tidak tersebar merata, maka tipe emulsi $\mathrm{A} / \mathrm{M}$.

Pengujian akseptabilitas dilakukan dengan meminta tanggapan 20 sukarelawan yang menggunakan lotion. Tanggapan yang diminta berupa warna, aroma, tekstur, kemudahan dicuci, dan kesan tidak lengket. Skala akseptabilitas yang digunakan yaitu 1-5. Persentase nilai yang diperoleh dapat dihitung menggunakan Persamaan 2.

$\mathrm{N}=\frac{\mathrm{Sp}}{\mathrm{Sm}} \times 100 \%$ 
Dimana :

$\mathrm{N} \quad=$ Persentase nilai akseptabilitas

$\mathrm{Sp} \quad=$ Rata-rata total skor yang diperoleh

$\mathrm{Sm}=$ Skor maksimum

Nilai persentase yang diperoleh dikatakan memiliki nilai akseptabilitas:

a. Sangat baik, jika nilai persentase $>80-100 \%$

b. Baik, jika nilai persentase $>60-80 \%$

c. Cukup baik, jika nilai persentase $>40-60 \%$

d. Kurang baik, jika nilai persentase $>20-40 \%$

e. Tidak baik, jikai nilai persentase $\leq 20 \%$

\section{Penentuan Nilai SPF Lotion}

Penentuan nilai SPF sediaan lotion ekstrak daun salam dilakukan dengan cara membuat larutan dengan konsentrasi 0,001\% dan 0,005\% menggunakan etanol p.a. Pengukuran dan perhitungan nilai SPF lotion sama seperti pada pengukuran dan perhitungan nilai SPF ekstrak daun salam, yaitu dengan menggunakan spektrofotometer UVVis pada panjang gelombang 290-320 nm dan menggunakan persamaan Mansur. ${ }^{15}$

\subsection{Hasil dan Diskusi}

\section{Hasil Simplisia}

Daun salam (Syzygium polyanthum (Wight) Walp.) yang digunakan sebagai sampel yaitu daun salam tua yang berwarna hijau tua. Hal ini dikarenakan berdasarkan penelitian yang dilakukan oleh Bahriul dkk (2014), aktivitas antioksidan ekstrak etanol daun salam tua memiliki nilai antioksidan yang paling tinggi dibandingkan dengan daun salam muda dan setengah tua.16

Daun salam dibuat dalam bentuk simplisia terlebih dahulu untuk mempermudah proses ekstraksi.Simplisia adalah bahan alami yang digunakan sebagai obat dan belum mengalami pengolahan apapun juga dan kecuali dinyatakan lain, berupa bahan yang telah dikeringkan.17 Tujuan pembuatan simplisia yaitu untuk memperoleh bahan yang tidak mudah rusak sehingga dapat disimpan dalam waktu yang lebih lama.18Simplisia daun salam yang diperoleh pada penelitian ini yaitu sebanyak 665 gram.

\section{Hasil Ekstrak}

$300 \mathrm{~g}$ serbuk simplisia daun salam diekstraksi dengan metode sonikasi selama $3 \times 15$ menit menggunakan pelarut etanol 96\%. Pelarut etanol $96 \%$ digunakan karena berdasarkan penelitian yang dilakukan oleh Islamiyati dan Ika (2018), ekstraksi daun salam menggunakan pelarut etanol 96\% menghasilkan aktivitas antioksidan yang lebih tinggi dibandingkan dengan ekstraksi menggunakan pelarut etanol $70 \% .19$

Setelah dilakukan proses ekstraksi, filtrat kemudian ditampung dan dikentalkan menggunakan rotary evaporator. Pemekatan dengan rotary vacum evaporator merupakan teknik pemekatan ekstrak tanpa merusak senyawa dari ekstrak, karena rangkaian alat ini menggunakan pompa vacum sehingga di dalam evaporator terjadi pengurangantekanan yang menyebabkan pelarut dapat menguap di bawah titik didihnya.20

Pemekatan ekstrak pada penelitian ini dilakukan pada suhu $40^{\circ} \mathrm{C}$ karena komponen bioaktif seperti flavonoid, tanin, dan fenol rusak pada suhu diatas $50^{\circ} \mathrm{C}$ karena dapat mengalami perubahan struktur serta menghasilkan ekstrak yang rendah.21 Pada penelitian ini, diperoleh berat ekstrak 45,1449 gram dan nilai rendemen ekstrak etanol daun salam yaitu sebesar $15,0474 \%$.

\section{Uji Fitokimia}

Uji fitokimia bertujuan untuk mengidentifikasi kandungan senyawa metabolit sekunder pada ekstrak daun salam (Syzygium polyanthum (Wight) Walp). Uji fitokimia pada ekstrak etanol daun salam menunjukkan ekstrak etanol daun salam mengandung senyawa metabolit sekunder fenolik, flavonoid, dan tanin. Hasil uji fitokimia ekstrak daun salam ditunjukkan pada Tabel 3.

Tabel 3. Hasil Uji Fitokimia Ekstrak Daun Salam

\begin{tabular}{ccc}
\hline Senyawa & Identifikasi Positif & Hasil Pengujian \\
\hline Fenolik & Ungu kehitaman & + \\
\hline Flavonoid & Jingga & + \\
\hline Tanin & Biru kehitaman & + \\
\hline Keterangan: $+=$ mengandung senyawa yang diuji \\
$-=$ tidak mengandung senyawa yang diuji
\end{tabular}

\section{Hasil Nilai SPF Ekstrak}

Hasil penentuan nilai SPF ekstrak etanol daun salam pada konsentrasi $0,001 \%$ dan $0,005 \%$ ditunjukkan pada Tabel 4

Tabel 4. Hasil Nilai SPF Ekstrak Daun Salam

\begin{tabular}{ccc}
\hline Konsentrasi Ekstrak & Nilai SPF \pm SD & Tipe Proteksi \\
\hline $0,001 \%$ & $5,34 \pm 0,02$ & Proteksi sedang \\
\hline $0,005 \%$ & $7,48 \pm 0,02$ & Proteksi ekstra \\
\hline
\end{tabular}

Berdasarkan hasil yang diperoleh, konsentrasi ekstrak 0,001\% memiliki proteksi sedang terhadap sinar UV-B dengan nilai $\mathrm{SPF} \pm \mathrm{SD}$ sebesar 5,34 $\pm 0,02$, sedangkan ekstrak 0,005\% memiliki proteksi ekstra terhadap sinar $\mathrm{UV}-\mathrm{B}$ dengan nilai $\mathrm{SPF} \pm \mathrm{SD}$ sebesar 7,48 $\pm 0,02$. Semakin tinggi konsentrasi ekstrak, maka semakin tinggi pula nilai SPF yang diperoleh.

Aktivitas tabir surya ekstrak daun salam dikarenakan adanya senyawa metabolit sekunder seperti fenolik, flavonoid, dan tanin. Ketiga senyawa tersebut memiliki gugus kromofor yang memiliki kemampuan untuk menyerap sinar dengan kuat pada kisaran panjang gelombang sinar UV.22 Molekul bahan kimia yang 
menyerap energi dari sinar UV akan mengalami eksitasi dari ground state ke tingkat energi yang lebih tinggi. Sewaktu molekul yang tereksitasi kembali ke kedudukan yang lebih rendah, akan melepaskan energi yang lebih rendah dari energi semula yang diserap untuk menyebabkan eksitasi. Sinar UV yang memiliki energi lebih rendah ini akan kurang atau tidak menyebabkan efek sunburn pada kulit.12Tabir surya organik bekerja dengan menyerap sinar UV seperti PABA (Para-aminobenzoic acid) dan oksibenzon, sedangkan tabir surya anorganik bekerja dengan menyerap, menyebarkan, atau memantulkan sinar UV seperti seng oksida dan titanium dioksida. 23

\section{Formulasi dan Evaluasi Sediaan Lotion}

Pada formulasi sediaan lotion ini, digunakan fase minyak dan fase air. Fase minyak terdiri dari asam stearat dan setil alkohol sebagai emulgator, parafin cair sebagai emolien serta propil paraben sebagai pengawet. Sedangkan fase air terdiri dari TEA sebagai emulgator, propilen glikol sebagai humektan, metil paraben sebagai pengawet, dan sisa air. Lotion ekstrak etanol daun salam dibuat sebanyak dua formula dengan konsentrasi ekstrak yang berbeda yaitu $0,1 \%$ (F1) dan 0,5\% (F2).Dasar pengambilan kedua konsentrasi tersebut yaitu mengacu pada penelitian yang dilakukan oleh Ratnapuri dkk (2020), dimana konsentrasi ekstrak 180 ppm memiliki nilai SPF pada kategori proteksi yang sama dengan sediaan krim dengan konsentrasi 18000 ppm. 24

Setelah dilakukan formulasi sediaan lotion ekstrak daun salam, kemudian dilakukan evaluasi sediaan yang terdiri dari uji organoleptis, homogenitas, tipe emulsi, daya sebar,daya lekat, $\mathrm{pH}$, dan akseptabilitas. Evaluasi sediaan yang pertama yaitu uji organoleptis. Hasil uji organoleptis lotion ekstrak daun salam ditunjukkan pada Tabel 5.

Tabel 5. Hasil Uji Organoleptis Sediaan

\begin{tabular}{|c|c|c|}
\hline \multirow{2}{*}{ Parameter uji } & \multicolumn{2}{|c|}{ Formula } \\
\hline & $\mathbf{F}_{1}$ & $\mathbf{F}_{2}$ \\
\hline Warna & Krem & Hijau kecoklatan \\
\hline Aroma & Ekstrak daun salam & Ekstrak daun salam \\
\hline Tekstur & Lembut & Lembut \\
\hline
\end{tabular}

Evaluasi yang kedua yaitu homogenitas. Uji homogenitas ini bertujuan untuk melihat dan mengetahui tercampurnya komponen-komponen sediaan.25 Hasil yang diperoleh yaitu tidak terdapat butiran-butiran kecil pada kedua formula tersebut sehingga dapat dikatakan homogen dan telah memenuhi syarat mutu sediaan tabir surya pada SNI 16-4399-1996.26 Evaluasi yang ketiga yaitu uji tipe emulsi. Uji ini bertujuan untuk mengetahui tipe emulsi dari sediaan, apakah tipe minyak dalam air (M/A) atau air dalam minyak (A/M). Hasil yang diperoleh yaitu zat warna methylene blue tersebar merata pada kedua formula sediaan sehingga dapat dikatakan bahwa sediaan lotionekstrak daun salam ini memiliki tipe sediaan M/A.

Evaluasi yang keempat yaitu uji daya sebar. Uji daya sebar bertujuan untuk melihat kemampuan penyebaran sediaan pada permukaan kulit, dimana sediaan diharapkan mampu menyebar dengan mudah pada saat dioleskan pada kulit tanpa menggunakan tekanan yang berarti.25 Hasil yang diperoleh yaitu diameter daya sebar pada F1 dan F2 berturut-turut sebesar $5,92 \pm 0,10 \mathrm{~cm}$ dan $6,05 \pm 0,11 \mathrm{~cm}$. Kedua formula ini telah memenuhi syarat daya sebar yang baik untuk sediaan topikal yaitu $5-7 \mathrm{~cm} .27$

Evaluasi selanjutnya yaitu uji daya lekat. Uji kelekatan lotion penting untuk mengevaluasi sejauh mana lotion dapat menempel pada kulit, sehingga efek terapi yang diharapkan bisa tercapai.28 Hasil yang diperoleh yaitu daya lekat pada F1 dan F2 berturut-turut sebesar 0,86 $\pm 0,06$ detik dan 0,78 $\pm 0,02$ detik. Kedua formula ini belum memenuhi syarat yang baik untuk sediaan topikal yaitu tidak kurang dari 4 detik.29 Hal ini dapat dikarenakan lotion merupakan sediaan kosmetik golongan emolien (pelembut) yang mengandung air lebih banyak.30

Evaluasi selanjutnya yaitu uji $\mathrm{pH}$. Uji $\mathrm{pH}$ ini bertujuan untuk mengetahui keamanan sediaan untuk diaplikasikan pada kulit. Kesesuaian nilai $\mathrm{pH}$ mempengaruhi penerimaan kulit terhadap sediaan. $\mathrm{pH}$ sediaan yang terlalu asam akan menimbulkan iritasi kulit, sedangkan $\mathrm{pH}$ yang terlalu basa dapat menyebabkan efek kering pada kulit.31 Hasil yang diperoleh yaitu $\mathrm{pH}$ pada pada F1 dan F2 berturut-turut sebesar 7,82 $\pm 0,03$ dan 7,74 $\pm 0,01$. $\mathrm{pH}$ dari sediaan lotion ekstrak daun salam ini telah memenuhi syarat $\mathrm{pH}$ pada sediaan tabir surya menurut SNI 16-4399-1996 yaitu 4,5-8,0.26Namunsemakin tinggi $\mathrm{pH}$, senyawa fenol yang terkandung di dalam ekstrak dapat mengalami kerusakan,32 sehingga dapat mempengaruhi hasil nilai SPF sediaan karena senyawa fenol merupakan salah satu senyawa yang berperan dalam penyerapan sinar UV.

Evaluasi sediaan yang terakhir yaitu uji akseptabilitas. Uji akseptabilitas bertujuan untuk mengukur derajat kesukaan dan penerimaan produk oleh konsumen.33Uji akseptabilitas pada penelitian ini dilakukan pada 20 responden. Berdasarkan persentase nilai akseptabilitas, parameter warna, tekstur, kesan lengket, dan kemudahan dicuci pada kedua formula memiliki nilai akseptabilitas yang sangat baik karena memiliki nilai lebih dari 80 . Sedangkan parameter aroma pada F1 memiliki nilai akseptabilitas yang paling rendah, yaitu sebesar 79\%.

\section{Hasil Nilai SPF Lotion}

Setelah dilakukan evaluasi sediaan, kemudian diuji nilai SPF secara in vitro menggunakan spektrofotometer UV-Vis dengan metode Mansur. ${ }^{15}$ Hasil nilai SPF yang diperoleh pada kedua formula disajikan pada Tabel 6

Tabel 6. Hasil Nilai SPF Sediaan 


\begin{tabular}{ccc}
\hline Formula & Nilai SPF \pm SD & Tipe Proteksi \\
\hline $\mathrm{F}_{1}$ & $4,97 \pm 0,06^{\mathrm{a}}$ & Proteksi sedang \\
\hline $\mathrm{F}_{2}$ & $6,72 \pm 0,10^{\mathrm{b}}$ & Proteksi ekstra \\
\hline Keterangan: & $\begin{array}{l}\text { Angka yang diikuti } \\
\text { menunjukkan berbeda signifikan }(\mathrm{p}<0,05)\end{array}$
\end{tabular}

F1 memiliki nilai SPF sebesar 4,97 yang berarti bahwa sediaan tersebut dapat menyerap $79,88 \%$ sinar UV, sedangkan F2 memiliki nilai SPF sebesar 6,72 yang berarti bahwa sediaan tersebut dapat menyerap $85,12 \%$ sinar UV.Nilai SPF dari F1 (konsentrasi ekstrak daun salam $0,1 \%$ ) memiliki tipe proteksi yang sama dengan $0,001 \%$ ekstrak, yaitu proteksi sedang. Demikian pula untuk lotion F2 (konsentrasi ekstrak 0,5\%) dengan ekstrak 0,005\% memiliki tipe proteksi yang sama, yaitu proteksi ekstra. Berdasarkan uji statistik dependent sample t-test, nilai SPF dari lotion F1 dengan ekstrak $0,001 \%$ serta lotion F2 dengan ekstrak $0,005 \%$ tersebut memiliki perbedaan yang signifikan karena nilai signifikansi $<0,05$.

Nilai SPF dari ekstrak daun salam ini mengalami sedikit penurunan setelah diformulasikan ke dalam sediaan lotion. Menurut Nuralifah dkk (2018), bahan tambahan pada sediaan mempengaruhi aktivitas ekstrak karena sediaan dapat menghambat pelepasan kandungan senyawa aktif dari ekstrak untuk berdifusi kedalam media, sehingga ekstrak yang terkandung dalam sediaan tidak terlepas sempurna dalam media. Oleh karena itu, aktivitas sediaan yang dihasilkan lebih rendah dibandingkan aktivitas ekstrak.34Faktor-faktor yang mempengaruhi pelepasan obat dari basis pada dasarnya sama dengan faktor-faktor yang mempengaruhi absorbsi pada saluran cerna dengan laju difusi yang sangat tergantung pada sifat fisika-kimia obat. Obat-obat terlarut yang terikat kuat oleh bahan pembawa seperti yang terjadi jika obat membentuk kompleks yang dapat larut dengan bahan pembawanya akan menghasilkan koefisien aktivitas yang rendah, dengan demikian laju pelepasan dari kombinasi obat-pembawa lebih lambat.35

Berdasarkan penelitian yang telah dilakukan, dapat disimpulkan bahwa formula sediaan lotion ekstrak daun salam yang digunakan yaitu $1 \%$ trietanolamin, $3 \%$ asam stearat, $2 \%$ setil alkohol, $15 \%$ propilen glikol, 2,5\% parafin cair, $0,2 \%$ metil paraben, $0,04 \%$ propil paraben, 3 tetes aqua rosae, aquades, serta ekstrak daun salam dengan konsentrasi ekstrak $0,1 \%(\mathrm{~F} 1)$ dan $0,5 \%(\mathrm{~F} 2)$. Karakteristik fisik sediaan lotion ekstrak daun salam telah memenuhi syarat pada uji homogenitas, daya sebar, dan $\mathrm{pH}$ serta tidak memenuhi syarat pada uji daya lekat. Nilai SPF sediaan lotion ekstrak etanol daun salam yang diperoleh yaitu 4,97 (F1) dan 6,72 (F2) dengan tipe proteksi sedang dan ekstra.

\subsection{Daftar Pustaka}

1. Widyastuti, Ariya EK, Nurlaili, Fitriani S. Aktivitas Antioksidan dan Tabir Surya Ekstrak Etanol Daun Stroberi (Fragaria $x$ ananassa A.N. Duchesne). Jurnal Sains Farmasi dan Klinis. 2016. 3(1):19-24.

2. Wiraningtyas A, Ruslan, Sry A, Uswatun H. Penentuan Nilai Sun Protection Factor (SPF) dari Ekstrak Kulit Bawang Merah. Jurnal Redoks : Jurnal Pendidikan Kimia dan Ilmu Kimia. 2019. 2(1):34-43.

3. International Agency for Research on Cancer. Global Cancer Incidence, Mortality and Prevalence World Wide. IARC Global Cancer Observatory;2020.

4. Dewiastuti M, Irma FH. Pengaruh Faktor-Faktor Risiko Penuaan Dini di Kulit Pada Remaja Wanita Usia 18-21 Tahun. Jurnal Profesi Medika.2016. 10(1):21-25.

5. Balakhrisnan KP, Nithya N. Botanicals as Sunscreen: Their Role in The Prevention of Photoaging and Skin Cancer. International Journal of Research in Cosmetics Science. 2011. 1(1):1-12.

6. Collins P, Ferguson J. Photoallergic Contact Dermatitis to Oxybenzone. British Journal of Dermatology.1994. 131:124-129. Whenny, Rolan R, Laode R. Aktivitas Tabir Surya Ekstrak Daun Cempedak (Artocarpus champeden Spreng). Jurnal Sains dan Kesehatan. 2015. 1(4):154-158.

7. Verawati, Dedi N, Petmawati. Pengaruh Metode Ekstraksi terhadap Kadar Fenolat Total dan Aktivitas Antioksidan Daun Salam (Sygygium polyanthum (Wight) Walp). Jurnal Katalisator. 2017. 2(2):53-60.

8. Soejanto, AS. Pemberian Krim Ekstrak Metanolik Buah Delima Merah (Punica granatum) Menghambat Penurunan Jumlah Kolagen Dermis Kulit Mencit (Mus musculus) yang Dipapar Sinar Ultraviolet B. Indonesian Journal of Anti Aging Medicine. 2017. 1(1):1-9.

9. Harismah H, Chusniatun. Pemanfaatan Daun Salam (Eugenia polyantha) sebagai Obat Herbal dan Rempah Penyedap Makanan. WARTA LPM. 2016. 19(2):110-118.

10. Hikmah N, Yuliet, Khildah K. Pengaruh Pemberian Ekstrak Daun Salam (Sygygium polyanthum Wight.) terhadap Glibenklamid dalam Menurunkan Kadar Glukosa Darah Mencit (Mus musculus) yang Diinduksi Aloksan. Galenika Journal of Pharmacy. 2016. 2(1):24-30.

11. Prasiddha IJ, Rosalina AL, Teti E, Jaya MM. Potensi Senyawa Bioaktif Rambut Jagung (Zea mays L.) untuk Tabir Surya Alami : Kajian Pustaka. Jurnal Pangan dan Agroindustri.2016. 4(1):40-45.

12. Putri YD, Haruman K, Intan L. Formulasi dan Evaluasi Losion Tabir Surya Ekstrak Daun Stevia (Stevia rebaudiana Bertoni M). Jurnal Sains Farmasi dan Klinis. 2019. 6(1):32-36.

13. Haeria, Surya N, Israyani. Penentuan Potensi Tabir Surya Ekstrak Klika Anak Dara (Croton oblongus Burm F.). JF FIK UIINAM. 2014. 2(1):1-5.

14. Donglikar MM, Sharada, LD. Sunscreens: A review. Pharmacognosy Journal. 2016. 8(3):171-179. 
15. Bahriul P, Nurdin R, Anang WMD. Uji Aktivitas Antioksidan Ekstrak Daun Salam (Syzygium polyanthum) dengan Menggunakan 1,1-Difenil-2- Pikrilhidrazil. Jurnal Akademika Kimia. 2014. 3(3):368-374.

16. Departemen Kesehatan Republik Indonesia. Parameter Standar Umum Ekstrak Tumbuhan Obat Edisi I. Direktorat Jenderal Pengawasan Obat dan Makanan;2000.

17. Sakka L. Identifikasi Senyawa Alkaloid, Flavonoid, Saponin, Dan Tanin Pada Jeruk Nipis (Citrus aurantifolia) di Kabupaten Bone Kecamatan Lamuru Menggunakan Metode Infusa. Jurnal Ilmiah Kesehatan Diagnosis. 2018. 12(6):670-674.

18. Islamiyati R, Ika NS. Uji Perbedaan Aktivitas Antioksidan dengan Variasi Konsentrasi Pelarut Etanol $70 \%$ dan $96 \%$ Pada Ekstrak Etanol Daun Salam Menggunakan Metode Peredaman Radikal Bebas DPPH. Cendekia Journal of Pharmacy. 2018. 2(2):134-142.

19. Siadi K. Ekstrak Bungkil Biji Jarak Pagar (Jatropha curcas) Sebagai Biopestisida yang Efektif dengan Penambahan Larutan NaCl. Jurnal MIPA. 2012. 35(1):7783.

20. Yuliantari NWA, Widarta IWR, Permana, IDGM. Pengaruh Suhu dan Waktu Ekstraksi Terhadap Kandungan Flavonoid dan Aktivitas Antioksidan Daun Sirsak (Annona muricata L.) Menggunakan Ultrasonik. Media Ilmiah Teknologi Pangan. 2017. 4(1):35-42.

21. Abdiana R, Dwi IA. Rambut Jagung (Zea mays L.) sebagai Alternatif Tabir Surya. Majority. 2017. 7(1):31-35. 22. Mancebo SE, Judy YH, Steven QW. Sunscreens: A Review of Health Benefits, Regulations, and Controversies. Dermatologic Clinics. 2014. 32(3):427-438.

23. Ratnapuri P, Destria IS, M Faris I, Marsya NP. Karakteristik Fisika dan Kimia Sediaan Krim Ekstrak Kulit BawangMerah (Allium ascalonicum) dengan Variasi Konsentrasi Ekstrak. Prosiding Seminar Nasional Lingkungan Lahan Basah. 2020. 5(2):36-41.

24. Gurning HET, Adeanne CW, Widya AL. Formulasi Sediaan Losio Dari Ekstrak Kulit Buah Nanas (Ananas comosus L.(Merr)) Sebagai Tabir Surya. Pharmacon.2016. 5(3):110-115.

25. SNI 16-4399-1996. Sediaan Tabir Surya. Jakarta: Badan Standardisasi Nasional; 1996.

26. Daud NS, Musdalipah M. Optimasi Formula Losio Tabir Surya Ekstrak Kulit Buah Naga Super Merah (Hylocereus costaricensis). PHARMACY: Jurnal Farmasi Indonesia (Pharmaceutical Journal of Indonesia). 2018. 15(1):26-37.

27. Voight R.Buku Pelajaran Teknologi Farmasi, Yogyakarta: Gajah Mada University Press;1995.

28. Ulaen, Selfie PJ, Banne, Yos S, Ririn A. Pembuatan Salep Anti Jerawat dari Ekstrak Rimpang Temulawak (Curcuma xanthorrhiza Roxb.). Jurnal Ilmiah Farmasi. 2012. 3(20):45-49.

29. Sularto SA. Pengaruh Pemakaian Madu sebagai Pensubstitusi Gliserin dalam Beberapa Jenis Krim
Terhadap Kestabilan Fisiknya. Laporan Penelitian, LP UNPAD. Bandung: Universitas Padjajaran;1995.

30. Sulastri E, Yusriadi, Dinda R. Pengaruh Pati Pragelatinasi Beras Hitam Sebagai Bahan Pembentuk Gel Tehadap Mutu Fisik Sediaan Masker Gel Peel Off. Jurnal Pharmascience, 2016. 3(2):69-79.

31. Dewandari, KT, Sri, Y, Sedarnawati Y. Ekstraksi dan Karakterisasi Nanopartikel Ekstrak Sirih Merah (Piper crocatum). J. Pascapanen. 2013. 10(2):65-71.

32. Kusuma TS, Adelya DK, Yosfi R, Ilzamha HR, Rahma MW. Pengawasan Mutu Makanan;2017.Vanishing Cream Terhadap Propionibacterium acne. Jurnal Farmasi, Sains, dan Kesehatan. 2018. 4(2):30-35. Terpurifikasi Daun Sirih (Piper betle L.) dengan Basis Vanishing Cream Terhadap Propionibacterium acne. Jurnal Farmasi, Sains, dan Kesehatan. 2018. 4(2):30-35.

33. Nuralifah, Fery IA, Parawansah, Aulif P. Uji Aktivitas Antibakteri Sediaan Krim Anti Jerawat Ekstrak Etanol Terpurifikasi Daun Sirih (Piper betle L.) dengan Basis Vanishing Cream Terhadap Propionibacterium acne. Jurnal Farmasi, Sains, dan Kesehatan. 2018. 4(2):30-35.

34. Lachman L, Lieberman HA, Kanig JL. Semi Padat, Teori dan Praktek Farmasi Industri, Edisi III, diterjemahkan oleh Suyatmi. Jakarta: Universitas Indonesia Press; 1994. 